\title{
Memória social e discurso regionalista na canção "Belém-Pará-Brasil"*
}

\author{
NÉLIO MOREIRA*
}

\begin{abstract}
RESUMO: Este trabalho é uma análise da gravação original da canção "Belém-Pará-Brasil", do grupo paraense de rock Mosaico de Ravena. O objetivo é tomar a música como um conjunto letra-sonoridade que, em seu constructo estético-político, propugna pressupostos identitários que, todavia, se encontram historicamente localizados - o final da década de 1980 , mas que se projetaram para além desse contexto de sua criação e preliminar circulação, sendo acionado como potência discursiva em outros, diversos e distintos, momentos e espaços sociais. Devido a essa sua característica discursiva, a canção se tornou um objeto de significação cultural destacado no campo da música popular da cidade, chegando mesmo a ser elevada à condição de um "hino". Por isso, é incontornável traçar uma relação entre as ações entoativas da sua economia sonoro-literal e uma memória social que se projeta a partir de então.
\end{abstract}

PALAVRAS-CHAVE: Belém-Pará-Brasil; identidade regional; memória social.

\section{Social memory and regionalist discourse in the song "Belém- Pará-Brasil"}

\begin{abstract}
This work is an analysis of the original recording of the song Belém-ParáBrasil, from the Paraense rock group Mosaico de Ravenna. The goal is to take this music as a lyrics-sound ensemble that, in its aesthetic-political construct, argues for identity presuppositions that, however, are historically located - the late 1980s - but which projected themselves beyond this context. Its creation and preliminary circulation, being actuated as discursive power in others, diverse and distinct, moments and social spaces. Certainly due to its discursive characteristic, the song has become an object of cultural significance highlighted in the field of popular music of the city, even being raised to the condition of a "hymn". Therefore, it is unavoidable to draw a relationship between the intonative actions of its soundliteral economy and a social memory projected thereafter.
\end{abstract}

KEYWORDS: Belém-Pará-Brasil song; regional identity; social memory.

\footnotetext{
* Este artigo foi desenvolvido a partir de um dos tópicos tratados no capítulo 3 da dissertação de mestrado A música e a cidade: práticas sociais e culturais na cena da canção popular em Belém do Pará na década de 1980, defendida no Programa de Pós-graduação em Sociologia e Antropologia da UFPA (PPGSA/UFPA), em agosto de 2014, sob a orientação do Prof. Dr. Antonio Maurício Dias da Costa.

** Nélio Moreira é Historiador. Mestre e Doutorando em Antropologia Social (UFPA). Professor Substituto no Instituto de Ciências da Arte da Universidade Federal do Pará (ICA/UFPA). E-mail: neliormoreira@gmail.com
} 


\section{Discurso regionalista em uma canção popular}

canção "Belém-Pará-Brasil" é peça-chave na história contemporânea da
música popular paraense. Trata-se de uma composição que tem relativo
destaque no cancioneiro local, notadamente pelo seu eficaz encadeamento forma-conteúdo: uma balada pop-rock, com polida construção harmônica e melódica, com uma interpretação vocal singular e que reitera o discurso direto e voraz em defesa do regionalismo. Lidar de uma maneira reativa com a situação de fronteirização da região em curso nos anos 1980 foi o que certamente muito contribuiu para o seu estabelecimento do seu circuito comunicacional da canção local. Todavia, ela não goza de uma unanimidade no meio musical local, justamente por esse seu apelo reativo, como se verá mais à frente. Ainda assim, a sua forma de falar da região como lócus de exploração e fronteira nos anos 1980 é o que a credencia a compor, ainda hoje, o repertório de shows musicais na cidade; dos artistas do mainstream local ao barzinho de voz e violão, passando pelos diversos Grupos de Expressão Folclórica locais "que atuam em defesa da região e da cultura popular", ela é integrante da coletânea musical nas apresentações.

De fato, ela se "cristalizou" de maneira indelével na memória social local e no mercado de bens simbólicos da cidade porque traça esse quadro sonorodiscursivo da "condição" histórica de Belém do Pará - nesse caso, cabe atentar que se trata de uma cidade que é acionada como projeção de uma região - no âmbito das investidas do capital nacional e internacional, mas também porque ela é composição que resulta de um contexto de transição: foi produzida e publicizada nos momentos que se seguiram à então recente abertura política ${ }^{1}$ e todas as consequências disso para aquela realidade regional, que já era historicamente marcada por uma conflituosa e conturbada relação com o Estado Nacional brasileiro.

Assim, "Belém-Pará-Brasil" canção surge como insurgência, em reação ao Estado nacional, no mesmo contexto em que outras músicas da cena rock brasileira vieram a público e se propuseram como questionadoras, ou mesmo negadoras, da preconizada unidade nacional fomentada pelo campo político (CAVALHO, 2004).

${ }^{1}$ O fim do regime militar foi em 1985. A composição é de 1987. 
Nesse sentido, é preciso considerar que a classificação dessa canção como do gênero rock (MONTEIRO, 2013; CASTRO; AMADOR, 2015) tem um peso. Isso porque a legitima em seu intento de insurgência, haja vista que o rock tem desde o seu nascimento, como um rótulo, ser uma música de caráter questionador, de protesto e associado à noção de juventude como sinônimo de vigor. Isso é parte das intenções próprias desse gênero, mas que se coadunam a outras demandas uso pela indústria cultural. ${ }^{2}$

Mas "Belém-Pará-Brasil" é aqui um tipo de canção popular porque é portadora, num sentido mais amplo, dos elementos fundamentais formativos que atendem a essa classificação, quais sejam: letra e música em uma estrutura melódica que se insere na categoria de música popular, não como o oposto de música erudita, mas como produto híbrido assentado em um suporte preciso, o que lhe dá uma segunda característica, que é a sua forma fonográfica perenizada na gravação (NAPOLITANO, 2007; TATIT, 2004). Por outro lado, para além dessa "classificação" técnica legitima-a empiricamente como canção o fato de ter participado de um festival de canção popular, o IV Festival de Música Canta Belém - FEMUCAB33, realizado no ano de 1989 pelo Serviço Social do Comércio - SESC-PARÁ (MOREIRA, 2014), o último grande evento musical, como festival, da década de 1980.

Como recurso metodológico, o procedimento consistiu em descrever analiticamente a canção e, a partir disso, fazer as ligações com pressupostos teóricos

\footnotetext{
${ }^{2}$ A classificação do produto musical em gêneros deve ser relativizada, pois se trata mais de uma organização em prol da finalidade de consumo deste produto, daí a necessidade de se estabelecer hierarquias. Esse processo dá o sentido para uso, interpretação e circulação de sentidos pela sociedade. Portanto, a "classificação" de gênero é elemento da indústria cultural. Segundo Jéder Janotti Jr., é a mídia que produz sentido e condições de reconhecimento de um gênero musical. Isso tem consequência nas práticas de sociabilidade, no consumo cultural e na representação do produto musical (JANOTTI JR., 2006). De toda forma, a segmentação em gênero é socialmente pertinente, pois legitima a conformação de sociabilidades especificas. No caso de "Belém-Pará-Brasil" é importante salientar a existência de uma contenda no que diz respeito a sua "classificação" na cena local: para os integrantes da cena do rock, ela não é rock, e para aqueles da cena da canção, não é uma canção.

${ }^{3}$ O IV FEMUCAB foi "o último grande evento musical" da decantada época de efervescência que grassou em Belém nos anos 1980, segundo a memória dos atores sociais envolvidos naquela cena musical. Dele saiu vencedora a canção "Coura", de autoria dos músicos Joãozinho Gomes e Mário Moraes, interpretada pelos cantores Walter Freitas e Rui Baldez. E a segunda colocada foi Belém-ParáBrasil, de autoria de Edmar Rocha Jr., interpretada pelo grupo musical Mosaico de Ravena que, segundo um interlocutor, testemunha ocular, "[Belém-Pará-Brasil foi] a real vencedora, porque era a que o público queria [...], e não a decisão do júri". Como se vê, por mais que seja uma fala que remete a um tempo ausente, é preciso considerar a sua importância como memórias num campo de discursos em disputa.
} 
acerca do tema e do campo social. Assim, é presentada a letra em sua totalidade, para uma compreensão do seu conjunto discursivo. Em seguida, é feito o desmembramento de suas partes numa sequência ditada pela sua própria construção literal-sonora. Esse procedimento permite relacionar letra e música, conteúdo e forma, com o contexto da discursivização contida na gravação original, haja vista que é objeto a gravação original em sua totalidade discursiva.

Dessa forma, o discurso e os recursos entoativos que a caracterizam conformam um campo estético-discursivo que está integrado, e em atuação recíproca, ao campo histórico social por meio de uma expressão sonora desse contexto. Aqui podemos tomar como sustentação dessa perspectiva a detecção de que o seu núcleo narrativo certamente atende à "agudeza intelectual" (WISNIK, 2001) do seu cancionista ${ }^{4}$ (TATIT, 2014). É uma composição na qual o cancionista engendrou à "fala" uma tradução estilizada da realidade regional como instância identitária.

Mas há outras leituras. Nos momentos que antecederam as comemorações dos "400 Anos de Belém", um dos maiores meios de comunicação do estado promoveu uma votação para escolha da canção que "representa" a cidade. "BelémPará-Brasil", "uma canção de protesto", foi a terceira colocada, com 6,46\% dos votos. ${ }^{5}$ Então, temos aí que ainda - o ano é 2015 - se trata de vê-la como um viés reativo, passados mais de duas décadas de sua primeira gravação, e quase três de sua composição. Por outro lado, a sua participação e o quociente de votos angariados permitem que se considere que seu discurso ainda é vigente.

Em "Belém-Pará-Brasil" cabe ressaltar a eficácia na junção letra (ideologia)-melodia(forma). Nesse sentido, seguimos Luis Tatit para corroborar a proposta de leitura da canção, quando diz que há três modelos de integração da melodia com a letra: um integração natural, o que está bem próximo da nossa forma

\footnotetext{
4 Aquele que faz o "cálculo" da relação entre melodia e letra, que combina recursos naturais, procedentes da sua fala cotidiana (linguagem verbal com suas entoações), com recursos musicais de estabilização sonora (afinação das alturas, definição das durações rítmicas etc.) e ainda programa o andamento (mais rápido ou mais lento) das canções com suas recorrências temáticas ou suas curvas melódicas (TATIT, 2014).

5 "Qual a música que marca os 400 anos de Belém?". Disponível em: http://g1.globo.com/pa/para/belem-400-anos/votacaomultimidia/2015/12/qual-musica-quemarca-os-400-anos-de-belem.html. Acesso: 16 dez. 2015.
} 
cotidiana de frases entoadas; a integração que ocorre sobre um motivo de celebração, ou seja no qual há formação de motivos, como a exaltação de algo; e por fim, uma integração baseada num processo de reestabelecimento dos elos perdidos, que buscam expressar sentimentos de ausência, distancia, perda, e a necessidade da reconquista. Assim, cada um desses modelos explora e se desdobra sobre um determinado campo de tessitura, levando a decisões musicais complementares, como a duração da entoação, do segmento melódico e da prevalência da temática, por exemplo (TATIT, 2008).

E nela encontramos elementos desses três modelos ao focarmos em sua tematização melódica ${ }^{6}$. Mas isso será desenvolvido nesta análise mais à frente. Por ora vejamos a letra da canção:

\section{Belém-Pará-Brasil ${ }^{7}$}

(Edmar Rocha Jr.)

(Parte declamada)

Região Norte,

ferida aberta pelo progresso

sugada pelos sulistas

e amputada pela consciência nacional

(Parte cantada)

Vão destruir o Ver-o-Peso

Pra construir um Shopping Center

Vão derrubar o Palacete Pinho

Pra fazer um condomínio

Coitada da Cidade Velha, que foi vendida pra Hollywood, pra ser usada como albergue no novo filme do Spielberg

Quem quiser venha ver

Mas só um de cada vez

Não queremos nossos jacarés tropeçando em vocês

A culpa é da mentalidade

Criada sobre a região

${ }^{6}$ Trata-se do campo de tessitura que proporciona à melodia suas possibilidades de expansão ou não (TATIT, 2008).

${ }^{7}$ Foi utilizado o suporte CD para o trabalho. Mas essa gravação original está disponível em vários sítios na internet. Pode ser acessada aqui https://www.youtube.com/watch?v=EJbi9rp0xhE. 
Por que é que tanta gente teme?

Norte não é com $M$

Nossos índios não comem ninguém

Agora é só Hambúrguer

Por que ninguém nos leva a sério?

Só o nosso minério

Quem quiser venha ver

Mas só um de cada vez

Não queremos nossos jacarés tropeçando em vocês

Aqui a gente toma guaraná

Quando não tem Coca-Cola

Chega das coisas da terra

Que o que é bom vem lá de fora

Transformados até a alma

sem cultura e opinião

O nortista só queria fazer

parte da Nação

Ah! chega de mal feituras

Ah! chega de tristes rimas

Devolvam a nossa cultura!

Queremos o Norte lá em cima!

Por quê? Onde já se viu?

Isso é Belém!

Isso é Pará!

Isso é Brasil!

Em uma construção melódica e harmônica sobre uma "balada-rock" o cancionista percebe elementos identitários que o circundam a fim de que isso possa corroborar para os intentos da sua enunciação ${ }^{8}$. Assim, essa canção, como artefato cultural, acabou por se tornar um marco no cancioneiro local porque trata dessa enunciação identitária reiteradamente ativada. Cabe citar que, todavia, ela não é unanimidade no âmbito da cena musical local, haja vista que essa sua narrativa acaba por provocar tensionamentos: há quem lhe impute uma leitura de que se trata de um inócuo e exagerado bairrismo, além de notar algo paradoxal: se a intenção dos atores sociais da cena e do circuito locais da época era ingressar no cenário musical nacional, então por que denegar o Estado nacional?

\footnotetext{
${ }^{8}$ A enunciação é o elemento que atrela a forma ao sentido. A enunciação é a integração da experiência social à organização linguística, ou seja, a palavra se metamorfoseia como signo dialético e ideológico no plano da linguagem, na prática do discurso, "a língua em sua integridade concreta e viva e não a língua como objeto da linguística" (BAKHTIN, 1997, p. 181).
} 
Mas, seja para criticá-la ou para tê-la como "uma legítima representante do ufanismo papa-chibé"9, "Belém-Pará-Brasil" é uma canção popular que ocupa importante lugar no panteão sonoro regional porque se trata de uma possibilidade discursiva "moderna e jovial" - um rock'n roll - de falar da histórica marginalização da região Norte (=Amazônia) pelo Brasil. E assim ela funcionou como elemento de síntese, atualização e ratificação das tradições inventadas que há muito preenchem o repertório simbólico e social da música popular paraense. Inclusive, já foi sugerido que "Belém-Pará-Brasil", ainda que travestida de outra forma expositiva, no conteúdo seguiria em uma mesma trajetória que a vincula às composições “regionalistas" feitas no Pará na década de 1970, haja vista que:

[...] a temática do regionalismo musical de protesto, tal como em Mosaico de Ravena, só foi perceptível a partir do final dos anos 70, na obra de Fafá de Belém e nas canções, em parceria, de Paulo André e Ruy Barata. Percebi que residia nestes três artistas uma tradição que influenciou na composição de “Belém-Pará-Brasil'” (SILVA, 2010, pp. 10-11). (Grifos meus).

Embora a pertinente, a proposta de ligá-la à linha evolutiva das canções regionais de "protesto", segunda a leitura que assim caracteriza a produção de Paulo André Barata e Ruy Barata - o que em certa medida a submete à influência destes -, deve ser relativizada, haja vista que se trata de lidar com produtos culturais datados. Por outro lado, como foi mostrado anteriormente, o rótulo que lhe foi atribuído pela imprensa local de que se trata de "uma música de protesto" em certa medida garante sentido a tal proposição.

Ainda nessa pegada, uma segunda assertiva que acena a esse seu caráter de "música de protesto" se encontra na seguinte passagem, fala do músico Marcelo Pyrull, que tocou as guitarras na gravação original da canção: “[Belém-Pará-Brasil] dizia o que à época o devia ser dito sobre a situação da região ante o resto do país [...] tinha qualidades de protesto que lhe eram inerentes" 10 . Então, como artefato musical de "protesto" teria sido isso o garantido do seu sucesso. Mas é preciso ter em conta aqui o fato de se trata de um produto comercial, ou seja, é um bem de consumo

\footnotetext{
${ }^{9}$ Papa-chibé é um termo que está associado a uma identidade regional amazônica-paraense. Tanto pode ser o chibé uma mistura de farinha de mandioca e água que resulta num mingau (uma papachibé) que serve de alimento, como também pode ser aquele que consome o mingau (o papa-chibé).

${ }^{10}$ Comunicação pessoal.
} 
cultural de comunicação como "material ideológico". Além do mais, deve-se considerar os interesses políticos dos mediadores culturais ao veiculá-la.

Em terceiro lugar, para além dessa "visão de dentro" como "música protesto", vale citar a letra da música como "representação imaginária" da região Amazônica tal como aparece em epígrafe do livro Amazônia, Amazônias, de Carlos Walter Porto Gonçalves, professor de Geografia da Universidade Federal Fluminense (GONÇALVES, 2005, p. 11). Portanto, esses três exemplos convergem na leitura de que e trata de uma ação discursiva de reação ao Estado Nacional.

De todo modo, foi esse mote que acabou por torná-la portadora e formadora de "opinião pública" num momento histórico que demandava isso. Então, pode-se pensar que se trata de um produto que lançou um discurso que, em retroalimentação, adensou-se cada vez mais. Esse processo foi fundamental para seu sucesso como produto de consumo regional, sendo apropriada e (re-) utilizada de acordo com os interesses de quem a executa ou a regrava.

A canção "Belém-Pará-Brasil" é a última faixa do único disco lançado pelo grupo de pop rock paraense Mosaico de Ravena, formado pelos músicos Edmar Rocha Jr., voz e principal compositor; PP D'Antona, contrabaixo; Marcelo Pyrull, guitarra; Eric Van, bateria; Leg, teclados. O grupo fez parte do cenário musical brasileiro entre os anos de 1986 e 1993, atuando de forma intensa e angariando grande destaque naquela cena. Segundo o jornalista Ismael Machado, o "Mosaico de Ravena" era uma cria típica do [gênero] pop brasileiro dos anos 80. Sua sonoridade era diversificada, trafegando do funk às baladas, do rock básico a experimentalismos diversos" (MACHADO, 2004, p. 33).

Intitulado Cave Canem, o disco foi lançado em novembro 1989. ${ }^{11}$ Portanto, o contexto no qual o disco veio a conhecimento público é o de ocorrência da "transição democrática" e instauração de um período da história do Brasil que foi chamado de Nova República. Esse momento se inicia com a eleição do primeiro presidente eleito pela via direta após os vinte anos de regime ditatorial militar.

\footnotetext{
11MOSAICO DE RAVENA. Cave Canem. (LP). Belém do Pará, 1989. Este disco foi relançado em 1992 com a inclusão da música "Matinta Pareira", de autoria do compositor e músico, ícone para a cultura regional paraense, Maestro Waldemar Henrique. A gravação inclusão dessa música foi feita durante uma apresentação da banda no extinto Presídio São José (MACHADO, 2004). Sobre Waldemar Henrique, cf. MOREIRA, 2011.
} 
Altamente conturbado e prenhe de incertezas, é nesse contexto que a manifestação da identidade local frente às imposições do Estado Nacional para a região encontrou campo fértil.

Ainda sobre a longa trajetória de incorporação compulsória e traumática da região no Estado brasileiro se firmou no imaginário das criações artísticas de âmbito regional de maneira consistente. Tratada historicamente como uma permanente região de fronteira, essa parte do país acabou por estabelecer no imaginário local uma tradição cultural reativa que buscou mostrar-se na forma de produções artísticas. E o meio mais viável foi a utilização tópica da temática regionalista, entendendo isso como um conjunto de noções que dão conta do sistema de representação simbólica que são ideologicamente relacionadas ao local. E o local é a circunstância dessas práticas socioculturais delimitadas não apenas espacialmente, mas também como complemento imaginário da realidade circundante.

Nesse sentido, a mais viável reação ao fato de o Estado Nacional brasileiro ter "esquecido" a região e ao processo de integração compulsória que recorrentemente é efetivada por esse mesmo Estado, ocorreu, principalmente, pelo uso de formas artísticas, pelo campo estético. Assim, a invenção do mito da resistência cabocla $^{12}$ - da resistência pautada pela afirmação cultural identitária - foi fator determinante para que ocorressem inúmeras discussões, utilizações e reutilizações da premissa de uma "identidade paraense como cultura peculiar" (CASTRO, 2011, p. 321), instaurando projeções que serviram como moto representativo. Esse é o caso de "Belém-Pará-Brasil". Como aponta Fábio Castro (2011), parece tratar-se de uma demanda de época, pois os anos os anos 1970 e 1980 foram eivados de propugnações identitárias no meio artístico local.

No campo nacional, teria sido uma tendência refletir sobre esse contexto como campo de possibilidades. Por isso ali teria ali existido uma geração de artistas brasileiros que angariaram reconhecimento porque procuram expor esteticamente suas visões de mundo naquele ambiente político ainda incerto e ainda sob a sombra

\footnotetext{
$12 \mathrm{O}$ termo caboclo é de amplo uso na região da Amazônia brasileira, como uma categoria de classificação social. Mas também é usado na literatura acadêmica para fazer referência direta aos pequenos produtores rurais que ocuparam historicamente a região. Todavia, no campo social é termo complexo e ambíguo, e que está associado a um estereótipo negativo (LIMA, 1999).
} 
da repressão e da censura. Um exemplo de reação a isso teria sido a afirmação do rock nacional oitentista como uma forma de expressão musical eficaz para comunicar essas visões, haja vista que se trata de um gênero com reconhecida tradição "subversiva", além do que sua estrutura harmônico/melódica/rítmica, geralmente direta e objetiva, possibilitava expressar de maneira clara uma narrativa de questionamento.

Portanto, o final dos anos 1980 foi essa época na qual vários cancionistas do meio rock tomaram como mote discursivo assertivas de questionamento/negação da República brasileira. Exemplos: a música "Que país é este" (incluída no disco de mesmo nome), da banda Legião Urbana é de 1987, mesmo ano de "Lugar Nenhum", do grupo Titãs (do disco Jesus não tem dentes no país dos banguelas); em 1988, Cazuza lança "Brasil" (faixa do disco Ideologia). São canções de compositores/bandas que viveram sua juventude sob a ditadura militar e se lançaram à cena nesse contexto de transição para a democracia. Assim, suas músicas não se furtaram a falar sobre isso: enfrentamentos à essa (Nova) República em sua continuidade com um regime anterior. Assim, se valendo do tom agressivo que o rock pôde lhes proporcionar, essas músicas questionam e/ou rejeitam a ideia de país/nação/pátria como expediente social em suas composições (CARVALHO, 2004).

De fato, essas canções intentaram e obtiveram êxito discursivo. Em grande medida porque o público também tinha seus questionamentos políticos. Nesse panorama podemos colocar, com as devidas proporções e ressaltando alguns pontos, "Belém-Pará-Brasil". Primeiro, porque é produto de uma banda da periferia do circuito nacional da música popular. Segundo, porque lança um regionalismo nativista reativo que funcionaria, como de fato funcionou, apenas para um público restrito. (E talvez devido a isso não logrou se tornar um produto da indústria cultural no circuito da música popular brasileira). De toda forma, em âmbito regional, ela se tornou uma das mais conhecidas e emblemáticas produções da safra oitentista, embora tenha se afirmado no circuito comunicacional local apenas nos anos 1990. Para agentes da mediação cultural atuantes na época, como o jornalista Ismael Machado, foi ao longo dessa década que ela angariou o status de maior representante 
da música popular paraense (MACHADO, 2004). Seguramente porque, como um rock, (=jovialidade, energia, voracidade) apresentava o ethos regionalista num campo que demandava reagir, expressar-se vorazmente. E tal padrão entoativo/reativo se imbricava às demandas daquele campo.

Como consequência desse sucesso atingiu patamares de execução e consumo elevados, e isso a levou a fazer parte do repertório das rádios locais que até então quase não tocavam musica paraense. E, cabe acrescentar, tocava nas rádios locais mesmo sendo uma música que extrapola os moldes de música para rádio, onde "tocou por mérito", segundo o seu compositor, Edmar Rocha Jr. ${ }^{13}$ : são mais de 5 minutos, dos quais o último é destinado para a performance de um grupo de músicos do Grupo Parafolclórico Tamba Tajá14 tocando um "autêntico carimbó de pau e corda"15. Certamente, a incorporação de um grupo de músicos tocando um carimbó (=tradição) na parte final de uma canção popular estilo pop-rock (=modernidade) obteve sucesso em dar mais ênfase à narrativa estético-ideológica regionalista. $\mathrm{O}$ seu discurso, assim veiculado, viu-se assim fortalecido ao manifestar a identidade regional como fala instituída, agora não apenas de maneira declarada, mas demonstrada.

\section{Produção de sentido pela canção}

Sobre o material sonoro-literário um primeiro ponto a ser observado é a referência ao lugar: a cidade, o estado e o país servem de título à canção numa construção paratextual que remete à forma como se escreve a identificação da origem de um produto - cidade, estado, país. Isso mostra que a intenção do título era relativizar a hierarquia cidade/estado/país - ou local/regional/nacional -, e assim

\footnotetext{
13 "Mosaico de Ravena: o desabafo se tornou hino". Jornal O Diário do Pará. Belém, 13 de janeiro de 2013.

14 Planta da região amazônica a qual se atribuem poderes místicos. Também é uma lenda da região e nome de uma composição do músico Maestro Waldemar Henrique, do ano de 1934, gravada pela cantora Fafá de Belém, em 1976, em disco homônimo.

15 Também chamado de "carimbó de raiz". É a formação de grupo de carimbó com instrumentos rústicos e artesanais, como um par de tambores, chamados "curimbós" (o significado etimológico é "pau oco ou furado que produz som", donde vem carimbó), maracás, banjo e flauta. Sobre a contenda formada na década de 1970 em torno dos defensores do "carimbó pau e corda" e os partidários do "carimbó moderno" Cf. COSTA, 2010.
} 
expor a chamada para que o regional/local pudesse ser estabelecido como um componente do conjunto nacional. Mas também isso enseja que se possa ler o título da música como a identificação de um produto, nesse caso como um meta-produto.

Como introdução à peça musical em si, há uma evocação narrativa que (re) apresenta o local como algo maculado pela ação do Estado nacional em sua associação ao grande capital especulativo, estes que estariam atuando associados na exploração dos recursos naturais da região. Vejamos, primeiramente, essa parte declamada, como gesto entoativo (TATIT, 2003), que ressalta a importância funcional da atuação da fala em tom de dramático, mas, ao mesmo tempo, potencialmente irascível, para o conjunto discursivo da canção:

\author{
Região Norte, \\ ferida aberta pelo progresso \\ sugada pelos sulistas \\ e amputada pela \\ consciência nacional
}

Por esse trecho, podemos inferir que se trata de um discurso que tem como mote uma leitura da forma como a região Norte (=Amazônia) é explorada pelos interesses capitalistas em conluio com o Estado numa polarização - ainda que o "Sul" não aparece - Norte/Explorado e Sul/Explorador. A questão então lançada diz respeito a contenda entre duas regiões que tiveram papel distintos na formação histórica do Estado Nacional brasileiro.

De certo, o cancionista usa essas informações em busca de eficácia simbólica. Assim, a leitura que propõe - na época, o compositor Edmar Rocha Jr. era estudante de Arquitetura na Universidade Federal do Pará, o que permite deduzir que a representação que propõe tem a carga ideológica de um "informante" imerso em um determinado contexto - tem a intenção de ser utilizado numa perspectiva de naturalizar a ideia de região, não considerando que "se os modos de produção escrevem a história no tempo, as formações sociais escrevem-na no espaço" (SANTOS, 1982, p. 15). Assim, segundo a entoação dramática do texto melhor teria sido para a história da região se ela não tivesse sido incorporada à nação brasileira como comunidade nacional imaginária (ANDERSON, 2008). Assim, usasse como referência histórica a interpretação de que desde os primeiros momentos da história 
nacional, passando pela compulsória e traumática incorporação efetiva ao Estado brasileiro, no ano de 1823, seu papel da região nesse desenrolar já estava estabelecido como fonte de exploração pela região "Centro-Sul" do país, genericamente chamados de sulistas em oposição ao "periférico" nortista da canção. 16

Assim, a voz performaticamente empregada nessa narração inicial tem esse tom dramático, mas ao mesmo tempo como uma aflição que carrega cera potência de revolta. A mensagem passada já nessa primeira parte da música mostra um conflito entre a consciência de se saber estar sendo prejudicado e a apatia diante dessa situação. Dessa forma a narração inicia após dois compassos no quais apenas os instrumentos são executados. Em seguida, ouve-se os "ataques" da bateria, a escala decrescente do teclado dentro de um campo harmônico que modula de Maior para Menor e retorna em um crescendo. Sobre os arpejos do teclado, da harmônica da guitarra e da nota tônica do contrabaixo se insere um vocalize, que segue um contracanto gutural que remete à estilização de um canto indígena. Em seguida, tem início a declamação sobre os acordes em tom menor da guitarra, das notas tônicas do contrabaixo e ao fundo o som do teclado. Essa sonoridade termina subitamente, seguindo o compasso de espera para o início da música.

\author{
Vão destruir o Ver-O-Peso \\ Pra construir um shopping center \\ Vão derrubar o Palacete Pinho \\ Pra fazer um condomínio
}

Nesta parte apresenta-se a descritivamente o lugar. Sob uma perspectiva negativista se apresentam os elementos em contradição: a ação humana/globalização capitalista vai fazer sumir um pedaço ${ }^{17}$ da cidade, talvez o mais tradicional e representativo (o "nacionalmente e internacionalmente conhecido" Mercado do Ver-

\footnotetext{
${ }^{16} \mathrm{O}$ conceito referencial "centro-periferia" é oriundo dos estudos do âmbito da economia política. No sentido de espacialidade, o termo "centro" pode ser usado em seu sentido geográfico, mas também no sentido metafórico. Como no Brasil se processou um acúmulo demográfico na região Sudeste, esta passou a ser definidora do estado político, econômico e cultural do restante do Brasil, ainda que a capital federal, Brasília, se situe no "centro" geográfico do território. Aqui a construção "centro-sul", portanto, atende a premissa geográfico-cultural, concomitantemente. Sobre o conceito "centroperiferia" Cf. BURKE, 2002.

17 Resumidamente, trata-se de um conjunto de territórios marcados por uma determinada sociabilidade que se faz um elemento fundamental na constituição do roteiro dos indivíduos. O pedaço é portador, portanto, de uma sociabilidade específica (MAGNANI, 1996).
} 
O-Peso $)^{18}$. No seu lugar será construído um shopping center. De patrimônio histórico, lócus representacional e reduto de sociabilidades diversas, o complexo do Mercado Ver-O-Peso seria substituído pela padronização arquitetural do - estritamente comercial - shopping center. Também patrimônio histórico, o Palacete Pinho dará lugar a um condomínio. Assim, um prédio historicamente representativo, que havia sido lugar de moradia "familiar" e ainda funcionava como reminiscência de um período de opulência que a cidade conheceu, o período em que a exploração das riquezas naturais da região produziram a belle èpoque amazônida na passagem do século XIX para o XX (SARGES, 2010), seria transformado em um lugar de moradia "coletiva". Ou seja, teria destruído o seu caráter histórico-simbólico e seria colocado no curso histórico-pragmático, no processo civilizatório ditado pelo capitalismo. Portanto, aqui temos que dois lugares de memória ${ }^{19}$ da cidade serão destruídos em função do utilitarismo capitalista.

Nota-se que a narrativa se passa no futuro. Isso está na trilha da tendência algo fatalista que recorrentemente é acionada nas leituras regionalistas de reativismo. E, nessa mesma linha de "desilusões e lamentos" sobre as ações do Estado Nacional brasileiro sobre a região, é acrescentado ao discurso a ameaça da ocupação internacional sobre a região, como mostra o trecho que diz:

\section{Coitada da Cidade Velha, que foi vendida pra Hollywood, pra ser usada como um albergue no novo filme do Spielberg}

Nessa passagem, o lugar originário do núcleo urbano belemense, o bairro da Cidade Velha, será transformado em estalagem para os trabalhadores do novo filme do cineasta estadunidense Steven Spielberg que, subentende-se, terá como cenário a região amazônica. Fica patente que se trata de uma crítica em metáfora ao

\footnotetext{
${ }^{18}$ Eleito pela votação da emissora acima citada como o "símbolo" que representa Belém nos seus 400 anos. Disponível em: http://g1.globo.com/pa/para/belem-400anos/votacaomultimidia/2015/12/qual-e-o-simbolo-dos-400-anos-de-belem.html. Acesso: 23 dez. 2015.

${ }^{19}$ A expressão "lugares de memória" - lugares sedimentados na história, mas com um intento de memória - foi criada pelo historiador francês Pierre Nora para se referir a lugares que são resultado de uma construção histórica e que despertam interesse devido ao seu valor como documento/monumento (NORA, 1993).
} 
imperialismo norte-americano. Cabe destacar ainda desta passagem a detecção de que, tal como na canção "Flor do Grão Pará" 20, há em "Belém-Pará-Brasil" uma antropomorfização da cidade, dando-lhe características de persona. E aqui se fecha o primeiro ciclo da canção, o que é seguido pelo refrão.

\author{
Quem quiser venha ver \\ Mas só um de cada vez \\ Não queremos nossos jacarés \\ tropeçando em vocês
}

O refrão de uma canção é um mote de reiteração (TATIT, 2003). Nessa parte, a canção tem seu tom modulado, de Lá Menor para Dó Maior, embora mantenha o mesmo andamento. Isso passa a ideia de retomada do vigor, em contraposição ao tom plangente que caracteriza a parte anterior. Na parte literal, já se anuncia a "permissão" - portanto, um aceno à "integração" - para o ingresso do estrangeiro na região, desde que esse respeite os elementos naturais que lhe formam, e que isso seja feito de maneira organizada, ordenada ("só um de cada vez") para que não haja uma interferência que venha a desequilibrar a "idílica" harmonia do ecossistema local ("Não queremos nossos jacarés tropeçando em vocês"). Temos aqui um recurso à ironia que contribui sobremaneira para a apreensão do discurso incutido.

\title{
A culpa é da mentalidade \\ Criada sobre a região \\ Por que é que tanta gente teme? \\ Norte não é com " $M$ "!
}

A segunda parte da canção se desenvolve no mesmo campo harmônico usado na primeira parte. Dessa vez o texto apresenta $o$ culpado pela visão pessimista que sobre a região: a mentalidade estrangeira - aqui entendida como a definidora das representações coletivas sobre a região - que tratou-a como um lugar exótico, perigoso. Em outra chave, aqui aparece a reação a essa visão da Amazônia como um

${ }^{20}$ Composição do músico Chico Sena. Está no disco Música do Pará - Série Música Popular de Belém. (LP) VI Festival da FCAP. Belém, 1986. Na eleição anteriormente citada, sobre a música representante dos 400 anos de Belém, ficou em $2^{\circ}$ lugar. 
lugar degradante21, um "inferno verde" 22 ("Norte não é com M"; não é "Morte"). Isso retoma a visão de que a região começou a perder quando passou a ser objeto de conhecimento sistemático, principalmente pelos europeus - processo que se consolidou no século XVII, mas que remete às primeiras incursões pela região ainda no final do XV. Desde então, é recorrente essa argumentação de que há uma constante expansão para o sertão amazônico em busca de coleta e extração dos seus recursos naturais que não respeita sua realidade. A explicação histórica aponta que, desde a época colonial, à região se aplacou a visão geopolítica utilitarista como "único" recurso para justificar que ela compusesse o projeto colonial português e, posteriormente, aqueles levados a cabo pelo Estado Nacional brasileiro (SAMPAIO, 2003; RICCI, 2003), o que se manteve ainda com as visões e projetos da República para a região (SECRETO, 2010; PETIT, 2003).

O trecho seguinte mostra o processo de transformação na identidade étnica, ao mesmo tempo em que busca esclarecer/defender sobre as acusações de que a antropofagia é uma caraterística negativa da cultura dos nativos da região. Ao mesmo tempo, parece há uma aceno a certa tristeza em que essa "antropofagia" não (mais) ocorra. E num crescendo da entoação, tem lugar acenos ao processo de globalização: os nativos amazônicos agora (com a globalização homogeneizadora?) consomem o hambúrguer, um alimento típico da cultura estadunidense. E, assim se vê novamente reminiscências ao imperialismo norte-americano.

Nossos indios não comem ninguém

Agora é só hambúrguer

Segue-se então a indagação: por que a região, seus habitantes, sua cultura, não tem direito a um tratamento respeitoso? Isso reverbera, num trocadilho entre

\footnotetext{
${ }^{21}$ Tal como pronunciava, nos meados do século XIX, a teoria do degeneracionismo pela escrita de Carl Von Martius, no texto Como se deve escrever a História do Brasil, de 1945, segundo a qual os elementos naturais do ambiente de floresta tropical impuseram uma degeneração aos povos que se deslocaram dos altiplanos andinos (incas) e ingressaram na região da planície. Assim, teria havido uma degeneração da capacidade moral e desintegração da cultura material e organização social daqueles povos que na região amazônica se estabeleceram (FUNARI, 2006).

22 A formulação da ideia de ser a Amazônia um sertão algo infernal remete ao livro "Inferno Verde", de Alberto Rangel, publicado em 1908. Cabe ressalvar que o termo sertão é forma reduzida de "desertão", termo usado na época da colonização portuguesa para indicar o espaço vazio que estava apartado do litoral.
} 
levar/tratar, pois apenas a "sua" riqueza natural - neste caso, o minério de ferro - é levado (=tratado) com seriedade?

\title{
Por que ninguém nos leva a sério?
}

Só o nosso minério

Nesse ponto, a canção dirige seu ataque às consequências da exploração de minério, à sua extração, beneficiamento e transporte. As riquezas minerais que foram descobertos no Pará na década de 1960 e intensamente extraídos nos anos que se seguiram conheceram um incremento nos investimentos nos anos 1970 e 1980. Isso propiciou o crescimento do volume extraído e, por conseguinte, o aumento no valor das exportações. O ápice esse processo é a segunda metade da década de 1980, quando se passou a utilizar a estrada de ferro Carajás - Ponta da Madeira, que liga aquele município paraense à cidade de São Luís, no estado do Maranhão, para escoamento do minério extraído em Carajás (PETIT, 2004). Disso era conhecedor o cancionista, e por isso tratou politicamente dessa questão na sua composição.

A terceira e última parte retoma o tema da globalização. É colocado como mote que próprios habitantes da região sucumbiram ao ditame cultural estrangeiro, pois já não se consome mais "as coisas da terra" - nesse caso, o guaraná23 modificada que foi a mentalidade local pela ideologia homogeneizadora da globalização capitalista, o que está representado pelo refrigerante Coca-Cola. Assim, os "nativos" da terra se viram destituídos da sua cultura, são não-conhecedores e/ou negadores desta. Como consequência dessa "aceitação", também já não têm capacidade de opinar sobre a própria realidade que lhes circunda.

\author{
Aqui a gente toma guaraná \\ Quando não tem Coca-Cola \\ Chega das coisas da terra \\ Que o que é bom vem lá de fora \\ Transformados até a alma \\ sem cultura e opinião
}

\footnotetext{
${ }^{23}$ O guaraná é um fruto da Amazônia usado para fazer refrigerante. De sabor doce, é uma bebida bastante popular na região, de propriedade estimulante, sendo, inclusive, usado como marcador de identidade.
} 
Diante desse perverso quadro o que resta, então, é uma súplica: “O nortista só queria fazer parte da Nação", o nortista como categoria utilizada para uma designação genérica ao belemense-paraense-amazônida. Nesta última parte, a letra trata de uma espécie de solicitação de "acesso" desse nortista ao Brasil, para que a região Norte deixe de ser "malvista" e "maltratada" pelos que a veem, e vem, de fora.

$\mathrm{Na}$ parte sonora ocorre uma modulação tonal que busca reiterar a proposta da performance vocal. Esta, por sua vez, visa reforçar o discurso evocado, na medida em que o conteúdo desse discurso se transmuta de denúncias e lástimas, algo passivo, a um desabafo, algo ativo. Acompanha essa mudança para uma "agressividade" vocal, o que sustenta a "agressividade" do discurso, uma "agressividade" instrumental: na bateria, nos acordes da guitarra - com efeitos de distorção - é aplicado um "peso", o que sustenta musicalmente a exposição do discurso cancional. Esse discurso busca acionar as propriedades valorativas da região, quando diz:

\author{
Ah! chega de malfeitura \\ Ah! chega de triste rima \\ Devolvam a nossa cultura! \\ Queremos o Norte lá em cima! \\ Por quê? Onde já se viu? \\ Isso é Belém! \\ Isso é Pará! \\ Isso é Brasil!
}

$\mathrm{Na}$ armação literária, uma sequência que associa os pares nacional $=$ mal feitura / regional = cultura, seguidos pela consonância rima/cima, é o preâmbulo ao passo seguinte, o desfecho declarativo de afirmação identitária do local em seu pleito de inserção dessa comunidade imaginada regional à comunidade imaginada nacional. Nesse ponto, a performance vocal é componente de destaque, haja vista a utilização com competência por parte do intérprete das possibilidades da sua extensão vocal num gutural "Brasil". Constante no momento inicial e componente em grande parte da canção, a serenidade rítmica-musical é substituída por uma inflexão na parte final. Isso é a base para a mudança que ocorre também na forma de expressar a parte ideológico-literária, na qual o canto se expressa no recurso a 
totalidade da extensão vocal do cantor. Assim, se condensam negação e afirmação numa última nota, um antitético falsete que emite a palavra "Brasil".

\section{Considerações finais}

Em suma, por haver se tornado uma (emblemática) "música regional" consolidada no imaginário local, "Belém-Pará-Brasil" acabou por se tornar um importante produto da cultura popular local e importante fornecedor de elementos constitutivos da identidade regional para leituras da cultura popular. Contudo, a questão do regionalismo ali tratada é uma questão candente que, no entanto, referese a um contexto preciso. Mas seu sentido discursivo promoveu contundentes debates entre os partidários de seus argumentos e os contrários a eles, pois, o que, de certa forma, se estendeu para os momentos seguintes. ${ }^{24}$ Dessa forma, pode-se afirmar que se trata de uma peça musical de destaque porque é material simbólico com potencial de uso de acordo interesses em voga, inclusive e âmbito político-partidário. Ademais, sua importância para o circuito comunicacional da canção local é ratificada nas reproduções e regravações que, embora recorram a novos arranjos, mantem as intenções de seu discurso efetivo.

Mas, a música é sempre suspeita, haja vista que do ponto de vista sociológico tem comprometimento com o sentido original de sua feitura, por um lado, e de outro é uma "terra-de-ninguém ideológica” (WISNIK, 1987). Ainda que haja várias possibilidades de interpretação, o que é consequência da inerente multivocalizacão do signo musical, porque cada um que ouve tem um nível de entendimento diferente do outro (CONTIER, 1991), "Belém-Pará-Brasil" se cristalizou como um discurso competente quase que unívoco; uma peça musical transmutada que tem elementos de política cultural, submetida a usos e abusos, mas também é uma prática discursiva de intenção de identidade que se assentou na memória social.

\footnotetext{
24 Para o historiador Marcio Couto, "a canção 'Belém-Pará-Brasil' é uma ode à cristalização da cultura, uma negação do sincretismo e da própria dinâmica da sociedade, uma visão ingênua e romântica da história". Disponível em: http://marciocoutohenrique.blogspot.com.br/2010/04/o-sincretismo-namusica.html Acesso: 19 nov. 2013.
} 
Assim, a região norte do Brasil, tal como é apresentada pela canção a partir de Belém, é um lócus simbólico no interior de um movimento regionalista pretensamente centrípeto, mas em um flerte com o nacional. E, como produto cultural significado socialmente, atende aos intentos do atávico apelo pela inserção da região ao escopo nacional, todavia reatualizado pelo contexto - anos finais da década de 1980 - e pela forma de expressão - um pop-rock.

\section{Referências}

ANDERSON, Benedict. Comunidades Imaginadas. São Paulo. Cia das Letras, 2008.

BAKHTIN, Mikhail. Problemas da poética de Dostoiévski. Rio de Janeiro: Forense Universitária, 1997.

BURKE, Peter. História e Teoria Social. São Paulo: Editora UNESP, 2002.

CANCLINI, Nestor Garcia. Consumidores e cidadãos: conflitos multiculturais da globalização. Rio de Janeiro: Editora UFRJ, 1999.

CARVALHO, José Murilo. “O Brasil de Noel a Gabriel”. IN: CAVALCANTE, Berenice;

CASTRO, Fábio Fonseca de. Entre o Mito e a Fronteira. Belém: Labor Editorial, 2011.

; AMADOR, Elielton Alves. “Identidade, territorialidade e fantasmaticidade no rock de Belém”. contemporanea | comunicação e cultura - v.13 - n.02 - maio-ago 2015 - p. 417-433.

CONTIER, Arnaldo Daraya. “Música no Brasil: História e Interdisciplinariedade Algumas Interpretações (1926-1980)". IN: História em Debate. Atas do XVI Simpósio Nacional de História, ANPUH/CNPQ, Rio de Janeiro, 1991. (pp. 151-189).

COSTA, Tony Leão. "Música, literatura e identidade amazônica no século XX: o caso do carimbó". ArtCultura, Uberlândia, v. 12, n. 20, p. 61-81, jan.-jun. 2010

FUNARI, Pedro Paulo; NOELLI, Francisco Silva. Pré-História do Brasil. São Paulo: Contexto, 2006.

GONÇALVES, Carlos Walter Porto. Amazônia, Amazônias. São Paulo: Contexto, 2005.

HABERMAS, Jürgen. A mudança estrutural da esfera pública: investigações quanto a uma categoria de sociedade burguesa. Rio de Janeiro: Tempo Brasileiro, 2003. 
GUIMARÃES, Alan Kardek. Belém aos 80: cultura e resistência. Belém: 2009. 1 DVD. Dur. 88 min.

JANOTTI JR., Jeder. “Música popular massiva e gêneros musicais: produção e consumo da canção na mídia". IN: Comunicação, Mídia e Consumo. Escola Superior de Propaganda e Marketing São Paulo. Vol. 3. No 7. Pp. 31-47. Jul. 2006.

LIMA, Deborah de Magalhães. “A construção histórica do termo caboclo: sobre estruturas e representações sociais no meio amazônico". IN: Novos Cadernos NAEA vol. 2, no 2 - dezembro 1999.

MACHADO, Ismael. Decibéis sob mangueiras. Belém no cenário do rock Brasil dos anos 80. Belém: Editora Grafinorte, 2004.

MAGNANI, José Guilherme Cantor. “Quando o campo é a cidade: fazendo antropologia na metrópole" IN: MAGNANI, Jose Guilherme C.; TORRES, L.L. Na metrópole: textos de antropologia urbana. São Paulo: EDUSP/FAPESP, 1996.

MOREIRA, Nélio Ribeiro. A música e a cidade: práticas sociais e culturais na cena da canção popular em Belém do Pará na década de 1980. (Dissertação de Mestrado) Universidade Federal do Pará. Instituto de Filosofia e Ciências Humanas. Programa de Pós Graduação em Sociologia e Antropologia, Belém, 2014.

. “Identidade amazônica e música regionalista na primeira metade do século XX: Waldemar Henrique e a perspectiva primitivista do Modernismo Brasileiro." Revista Estudos Amazônicos. Vol. VI, nº 2 (2011), pp. 139-165.

MONTEIRO, Keila Michelle Silva. “O rock na Amazônia: peculiaridades desse gênero na história da música urbana em Belém do Pará". I Congresso Internacional de Estudos do Rock. UNIOESTE, Cascavel, Paraná. Setembro de 2013.

NAPOLITANO, Marcos. História e Música: História cultural da música popular. São Paulo: Autêntica, 2002.

NORA, Pierre. "Entre memória e história: a problemática dos lugares". Projeto História. São Paulo: PUC-SP, N 10, 1993.

PETIT, Pere. Chão de Promessas: elites politicas e transformações econômicas no estado do Pará pós-1964. Belém:Paka-Tatu, 2003.

RICCI, Magda. “O fim do Grão-Pará e o nascimento do Brasil: Movimentos sociais, levante e deserções no alvorecer do novo Império (1808-1840)". IN: GOMES, Flávio dos Santos; Mary Del Priori (Orgs). Os Senhores dos Rios: Amazônia, margens e história. Rio de Janeiro: Elsevier, 2003. (pp. 165-193).

SAHLINS, Marshall. Ilhas de história. Rio de Janeiro: Jorge Zahar, 1990. 
SAMPAIO, Patrícia. “Administração Colonial e Legislação Indigenista na Amazônia Portuguesa” IN: GOMES, Flávio dos Santos; DEL PRIORI, Mary (Orgs). Os Senhores dos Rios: Amazônia, margens e história. Rio de Janeiro: Elsevier, 2003. (pp. 165-193)

SANTOS, Milton. “Sociedade e espaço: a formação social como teoria e como método”. IN: Espaço e sociedade: ensaios. Petrópolis: Vozes, 1982. (pp. pp.9-27).

SARGES, Maria de Nazaré. Belém: Riquezas produzindo a Belle-Époque (1870-1912).

Belém: Paka-Tatu, 2010.

SECRETO, Maria Verônica. “Conquistar a terra, dominar a água, sujeitar a floresta: a fronteira amazônica no Governo Vagas". IN: ALONSO, José Luis Ruiz-Peinado; CHAMBOULEYRON, Rafael. T(r)ópicos de História: gente, espaço e tempo na Amazônia (séculos XVII a XXI). Belém: Editora Açaí/PPHIST(UFPA)/Centro de Memória(UFPA), 2010.

SILVA, Edilson Mateus Costa da. Ruy, Paulo e Fafá: identidade amazônica na canção paraense. Dissertação (Mestrado) - Universidade Federal do Pará, Instituto de Filosofia e Ciências Humanas, Programa de Pós-Graduação em História Social da Amazônia, Belém, 2010.

STARLING, Heloisa Maria Murgel; EISENBERG, José. Decantando a República: inventário histórico e político da canção popular moderna brasileira. Rio de Janeiro: Nova Fronteira; São Paulo: Fundação Perseu Abramo, 2004. (pp. 23-44). (Vol.2 - Retrato em branco e preto da nação brasileira).

TATIT, Luiz. “Elementos para análise da canção popular”. IN: Cadernos de Semiótica Aplicada. Vol. 1, n 2, dezembro de 2003.

. Elos de Melodia e Letra: análise semiótica de seis canções. Cotia, SP: 2008.

. “O "cálculo" subjetivo dos cancionistas". Revista do Instituto de Estudos

Brasileiros, Brasil, n. 59, p. 369-386, dez. 2014.

VILLAÇA, Mariana. “Propostas metodológicas para a abordagem da canção popular como documento histórico". Anais do II Simpósio Latino-Americano de Musicologia. Fundação Cultural de Curitiba, 1999.

WISNIK, José Miguel. “A gaia ciência: literatura e música popular no Brasil”. IN: MATOS, Cláudia Neiva (Org.). Ao encontro da palavra cantada. Rio de Janeiro: 7 Letras, 2001. (pp. 183-199).

“Algumas questões de música e política no Brasil". In: BOSI, Alfredo (org.).

Cultura e Política. Temas e situações. São Paulo: Ática, 1987. (pp. 114-123) 